\title{
Significant heterogeneity in hand hygiene compliance between different physician groups
}

\author{
O Yow*, S Callery, M Vearncombe \\ From International Conference on Prevention \& Infection Control (ICPIC 2011) \\ Geneva, Switzerland. 29 June - 2 July 2011
}

\section{Introduction / objectives}

Although hand hygiene $(\mathrm{HH})$ is known to be the single most important factor to reduce healthcare acquired infections, studies of $\mathrm{HH}$ compliance in health care workers (HCWs) has been reported to be between 30$50 \%$. Physician HH compliance is consistently lower than other HCWs. Whether the physician group is homogeneous with regard to $\mathrm{HH}$ compliance is uncertain. This study examines the $\mathrm{HH}$ compliance between different physician groups.

\section{Methods}

Designated auditors were trained to perform $\mathrm{HH}$ audits in all inpatient and long term care units of our 1185bed academic tertiary medical centre. The auditors used a standardized validated tool to audit HCW's HH during their patient interactions. The physician group was separated into 3 categories according to their seniority: staff physician, resident/fellow physician and medical student. When the auditors are unsure which category a physician belongs to, they ask for verbal confirmation. The $\mathrm{HH}$ compliance of the three physician groups was compared.

\section{Results}

Between Oct 2010 and Feb 2011, a total of $8337 \mathrm{HH}$ opportunities were observed. 1292 (15\%) opportunities were observed in the physician group: 486 opportunities were observed in staff physicians, 693 in resident/fellow physicians, and 113 in medical students. The overall average hospital compliance was $79 \%$; overall physician group compliance was $65 \%$. Among the physician group, staff physicians compliance was $71 \%$, resident/fellow physicians was $61 \%$ and medical students was $67 \%$. The

Infection Prevention and Control, Sunnybrook Health Sciences Centre, Toronto, Canada difference between staff physicians and resident/fellow physicians was statistically significant.

\section{Conclusion}

There is marked heterogeneity in $\mathrm{HH}$ compliance between staff physicians and resident/fellow physicians. The capability to detect such differences is important to direct compliance improvement efforts, with the goal of improving overall $\mathrm{HH}$ compliance.

\section{Disclosure of interest}

None declared.

Published: 29 June 2011

\section{doi:10.1186/1753-6561-5-S6-P121}

Cite this article as: Yow et al:: Significant heterogeneity in hand hygiene compliance between different physician groups. BMC Proceedings 2011 5(Suppl 6):P121.

\footnotetext{
Submit your next manuscript to BioMed Central and take full advantage of:

- Convenient online submission

- Thorough peer review

- No space constraints or color figure charges

- Immediate publication on acceptance

- Inclusion in PubMed, CAS, Scopus and Google Scholar

- Research which is freely available for redistribution

\section{Biomed Central}

(c) 2011 Yow et al; licensee BioMed Central Ltd. This is an open access article distributed under the terms of the Creative Commons Attribution License (http://creativecommons.org/licenses/by/2.0), which permits unrestricted use, distribution, and reproduction in any medium, provided the original work is properly cited. 